\title{
Bono Made Jesse Helms Cry: Jubilee 2000, Debt Relief, and Moral Action in International Politics
}

\author{
Joshua William Busby \\ LBJ School of Public Affairs, University of Texas
}

\begin{abstract}
Do states and decision-makers ever act for moral reasons? And if they do, is it only when it is convenient or relatively costless for them to do so? A number of advocacy movements - on developing country debt relief, climate change, landmines, and other issues-emerged in the 1990s to ask decision-makers to make foreign policy decisions on that basis. The primary advocates were motivated not by their own material interests but broader notions of right and wrong. What contributes to the domestic acceptance of these moral commitments? Why do some advocacy efforts succeed where others fail? Through a case study of the Jubilee 2000 campaign for developing country debt relief, this article offers an account of persuasion based on strategic framing by advocates to get the attention of decision-makers. Such strategic but not narrowly self-interested activity allows weak actors to leverage existing value and/ or ideational traditions to build broader political coalitions. This article, through case studies of debt relief in the United States and Japan, also links the emerging literature on strategic framing to the domestic institutional context and the ways veto players or "policy gatekeepers" evaluate trade-offs between costs and values.
\end{abstract}

Consecrate the fiftieth year and proclaim liberty throughout the land to all its inhabitants. It shall be a jubilee for you; each one of you is to return to his family property and each to his own clan (Leviticus 25:10).

In September 2000, the Irish rock star Bono met with North Carolina's Senator Jesse Helms and urged the conservative head of the Senate Foreign Relations Committee to support developing country debt relief. Helms was known for

\footnotetext{
Author's note: I thank colleagues from Georgetown University, the Brookings Institution, Harvard University's Belfer Center for Science and International Affairs, Princeton University's Center for Globalization and Governance, and three anonymous reviewers for comments on this project. I also thank students from Georgetown and Mannheim University as well as Bethany Albertson, Rosa Alonso, Jeffrey Anderson, Francis Beer, Andrew Bennett, Carl Brenner, Mark Copelovitch, Thomas Callaghy, James Davis, Kelly Greenhill, G. John Ikenberry, Patrick Jackson, Sarah Knight, Richard Ned Lebow, Jeff Legro, Jon Monten, Rodger Payne, Jon Rosenwasser, Thomas Risse, Frank Schimmelfennig, Sidney Tarrow, Leslie Vinjamuri, Mark Warren, and Thomas Wright for their helpful comments on earlier iterations. Thanks to Raymond Hicks for valuable suggestions for data. Special thanks go to those who agreed to be interviewed. These include David Bryden, Sonny Callahan, Jamie Drummond, Stephanie Flanders, Dan Driscoll-Shaw, Alan Gill, Scott Hatch, Thomas M. Hart, Nicola Jenns, Mark Lagon, Adrian Lovett, Jamie McCormick, Larry Summers, Susan Thompson, as well as other officials and advocates who provided me with invaluable background information.
} 
equating foreign aid with throwing money down "ratholes." However, after their meeting, Helms embraced debt relief and, later, funding to combat AIDS in the developing world. How can we explain this change? Bono claimed that Helms wept when they spoke: "I talked to him about the Biblical origin of the idea of Jubilee Year.... He was genuinely moved by the story of the continent of Africa, and he said to me, 'America needs to do more.' I think he felt it as a burden on a spiritual level" (Dominus 2000:6). Of his meeting with Bono, Helms said, "I was deeply impressed with him. He has depth that I didn't expect. He is led by the Lord to do something about the starving people in Africa" (Wagner 2000). The story of Helms' tears may be apocryphal, but it speaks both to the peculiar religiosity of the United States and more generally to the power of a compelling frame to persuade key veto players or "policy gatekeepers" to support a morally motivated policy. This article, through a case study of the Jubilee 2000 campaign for debt relief, seeks to explain how states may be moved to support "moral action.",

In the post-Cold War era, advocacy movements emerged to pressure the advanced industrialized world to address a number of new issues. The cases were distinctive because the primary advocates were motivated by broader notions of right and wrong rather than their own material interest. Issues that fell under this rubric included campaigns for the International Criminal Court, fair trade, religious freedom in China and the Sudan, as well as campaigns against global warming, AIDS, child labor, landmines, the "blood" diamond trade, small arms, and sweatshops. Under what conditions are these efforts successful? When will states take on these new normative commitments? As Price notes, the next generation of this kind of research needs to answer: "why do some campaigns succeed in some places but fail in others?" (Price 2003:586). Through a case study of the Jubilee 2000 campaign for developing country debt relief, this piece seeks to answer those questions and add to the emerging literature on transnational social movements. This article develops a generalizable argument about strategic framing and the ways in which advocates seek to tap into the values of the polities they are targeting and get the attention and support of "policy gatekeepers," potential veto players able to block policy change.

The Jubilee 2000 campaign - the campaign to write-off the external debt of the world's poorest countries - provides an interesting case study. The case is a puzzle because some states acted contrary to their narrow material interests, apparently at the behest of a transnational advocacy group. This case is also puzzling because debt negotiations are normally discussed in a rarefied world of central bankers and Treasury officials, multilateral bureaucrats, and private financiers, nearly all of whom are committed to minimizing moral hazard and are thus skeptical of writing off external debts. Two economists called the campaign "by far the most successful industrial-country movement aimed at combating world poverty for many years, perhaps in all recorded history" (Birdsall and Williamson 2002:1). It earned the endorsement of leaders of diverse ideological and professional orientations - the Pope, Bono, Jeffrey Sachs, and Pat Robertson. The campaign earned the support of strong political allies in the U.K. and U.S. governments, making it harder for other creditors - such as Japan, France, and Germany - to oppose debt relief.

Organized around the coming of the twenty-first century, Jubilee 2000 was an international campaign that aimed to relieve the world's poorest countries of their "unpayable" external debts. The reference to Jubilee comes from the Biblical notion in the Book of Leviticus of a time to relieve the debts of the poor. In the early 1990s, Martin Dent, a professor at Keele University in the United Kingdom, came up with the idea for a "Jubilee year" end of the millennium campaign, inspired by his knowledge of the Bible and ethical commitment to the third world (Dent and

${ }^{1}$ I follow other work on the role of morality in foreign policy by McElroy (1992) and Lumsdaine (1993). 
Peters 1999). Dent's advocacy began with his students but soon attracted Christian Aid, the World Development Movement, and other U.K. charities. Jubilee 2000 was formally launched in April 1996. The movement blossomed, galvanizing millions worldwide to participate in letter-writing efforts and protests before the official campaign closed at the end of 2000. In policy terms, Jubilee 2000's efforts moved donors to more than double the amount of debt relief on offer; by May 2006, 19 states already qualified to have $\$ 23.4$ billion of their debts written off through the HIPC initiative (World Bank 2006). In 2005, a successor campaign was able to induce rich creditors to commit to write-off $100 \%$ of the debts the poorest countries owed to the World Bank, IMF, and the African Development Bank. Moreover, the liberal-religious conservative coalition that came together on debt relief presaged advocacy efforts that would play an important role in the Bush Administration’s $\$ 15$ billion financial commitment to fight AIDS.

While debt relief is interesting in its own right, this article offers a useful framework for classifying cases and assessing the likelihood of the success of advocacy efforts across a range of phenomena. The piece is divided into six sections. The first section locates this paper in the wider scholarly debate. The second section develops a strategic framing/policy gatekeepers explanation for when advocacy movements are likely to succeed. The third section provides additional background on debt relief. The fourth section develops a partial explanation for support for debt relief and compliance patterns based on material interest and describes its limitations. The fifth section discusses how strategic framing/policy gatekeepers improves upon material interest arguments. The sixth section explores the causal processes of debt relief in the United States and Japan. The article employs qualitative case studies including typologies and process-tracing. ${ }^{2}$

\section{Contribution to International Relations}

This article seeks to overcome limitations of the main schools of thought in international relations theory. The dominant traditions-neorealism and neoliberalism-assume the state as unitary actor has interests that can be objectively read from conditions in the international system. The major difference between them is in their assessments of how much cooperation can be fostered by institutions. Thus, both are based on material interest where states respond to calculations of cost/ benefit. ${ }^{3}$ Neither looks inside the state to examine the impact of domestic politics nor are these approaches able to account for actors being motivated by moral concerns. While rational choice and pluralist approaches get at the micro-foundations of state behavior, actors are primarily, though not essentially, understood to be self-interested maximizers of material utility. ${ }^{4}$ Another theoretical approach - constructivism - takes ideas, culture, and values more seriously but has difficulty explaining under which conditions ideational factors and norms matter (Kowert and Legro 1996:486; Checkel 1997:476). By norms, the emphasis is on regulatory norms, the social conventions or rules, procedures, and principles that establish the standards of behavior for members of a group in a given context (Finnemore and Sikkink 1999:251). This notion of "oughtness" has been termed the logic of appropriateness. In contrast to the logic of consequences, where actors are motivated by the costs and benefits of different actions, logics of appropriateness reflect notions of right and wrong, of good and bad ethical behavior (March and Olsen 1998).

\footnotetext{
${ }^{2}$ These methods are appropriate for small-to-medium $\mathrm{N}$ research where statistical analysis is not possible and where we are interested in mid-range generalizations about politics and understanding of causal mechanisms. For an extended discussion, see George and Bennett (2005).

${ }^{3}$ The "neoutilitarian" foundations of realism and neoliberalism were noted by Ruggie (1999).

${ }^{4}$ Most "liberal" accounts emphasize rational action in terms of material interest (Milner 1997). Moravcsik's discussion of ideational and republican liberalism is an exception (Moravcsik 1997).
} 
While systemic incentives shape and shove states, domestic-level constraints coupled with the agency of actors themselves are important if we wish to explain foreign policy outcomes. Inspired by scholarship on "two-level games," my research gets at the question of when ideas and norms matter by focusing on the domestic acceptance of international agreements (Putnam 1988). As I argue in the article, in institutional contexts characterized by few policy gatekeepers, the key decision occurs at the time of international negotiation. In settings with multiple actors that can block policy change, the key decision occurs after an agreement has been negotiated and decision-makers have to take it home for approval. In the case of a treaty like the Kyoto Protocol, this means domestic ratification. For other types of agreements, this may involve an appropriation process. This article focuses on "empowerment" when states first pass measures in support of a norm (Checkel 1997:479). It is related to more long-lived processes of compliance (Simmons 1998). However, rather than ask "when do states accept new norms?" it may be helpful to focus on when states accept norms-based policies. While a norm is often abstract, a norm-based policy reflects a situation where activists have claimed injustices need redress. In the case of debt relief, advocates believe high levels of third world external debt constitute a wrong that creditor nations have a moral obligation to address. In response to their activism, a policy was drafted. Thus, the norm ("the unpayable debts of the poorest countries ought to be forgiven") becomes embodied in a policy (the Highly Indebted Poor Country initiative). States may accept a policy without embracing the norm, and even if the policy is accepted, advocates may remain unsatisfied that the norm remains unfulfilled.

The Jubilee 2000 was a political success in that creditor governments accepted deeper debt reduction at the G-8 Cologne Summit in 1999. Political success is different from policy success. It is too soon to write a definitive judgment of whether or not the problem has been ameliorated. Actual debt relief has been modest. The campaign's long-term impact is still open, as is true for most campaigns of the 1990s. How does such political success come about? In their search for mechanisms by which states come to embrace norms-based policies, scholars have identified coercion and persuasion as two primary mechanisms. ${ }^{5}$ Early accounts of persuasion by Finnemore and Sikkink ultimately relied on more instrumental pressure from lobbying and strategic use of language. Several scholars influenced by Jürgen Habermas' theory of communicative action have differentiated "true" persuasion from rhetorical action, distinguishing a logic of argumentation distinct from logics of consequences and appropriateness (Risse 2000). "True" persuasion ideally involves situations cleaved of material and social power; such accounts of persuasion are based on a mechanism of dialogue, consensus, and actors embracing norms as a result of deeper preference change (Payne 2001). This portrait of political change may be rather rare in political life (Jackson and Krebs 2003:6).

Those that study processes of norms diffusion recognize this, suggesting that in pluralistic liberal polities like the U.S., advocates of norms generally succeed through instrumental pressure/lobbying. Persuasive dynamics of social learning are thought to occur in more statist regimes (Checkel 1999:89; Checkel 2001). However, this move concedes too much empirical terrain to explanations that rely on coercion, material sanctions, and political pressure. We can identify the range of mechanisms by which states may accept a norms-based policy on a Coercion-Conversion continuum (see Figure 1). On one extreme, military action forces a state to accept a policy. On the other, policy-makers undergo an epiphany once presented with arguments in favor of a policy. In between, a variety of mechanisms exist to induce changes in state behavior.

${ }^{5}$ For surveys of these mechanisms, see Cortell and Davis (2000) and Cardenas (2004). 


\begin{tabular}{|c|c|c|c|c|}
\hline Coercion & Negative Incentive & Positive Benefit & Attention Shift & Conversion \\
\hline $\begin{array}{l}\text { Military } \\
\text { Force }\end{array}$ & Sanctions & $\begin{array}{l}\text { Reward, } \\
\text { Praise }\end{array}$ & $\begin{array}{l}\text { Strategic Framing } \\
\text { (Rhetorical Action) }\end{array}$ & $\begin{array}{l}\text { Consensual Dialogue } \\
\text { (Communicative Action }\end{array}$ \\
\hline
\end{tabular}

FIG. 1. Coercion-Conversion Continuum

Drawing on the social movement literature, scholars have recognized that framing, the strategic use of rhetoric, by advocates is a particularly potent strategy by which weak actors are able to exercise influence and induce states to embrace new policy commitments inspired by norms (Betsill 2000; Sell and Prakash 2004). Such "symbolic politics" are necessary given the relative weakness of proponents and because norms emerge "in a highly contested normative space where they must compete with other norms and perceptions of interest" (Finnemore and Sikkink 1999:257). Advocacy movements for these new international issues rarely have sufficient political power to alter elections. However, advocates can shape the general image and reputation of decision-makers through praise and shame, making them "look good" or "look bad." The less coercive side of framing appeals to mass publics and policy-makers, engaging them on grounds they agree with already. If advocates' appeals to decision-makers' existing values initially fall short, they and their allies can become more coercive, beginning with shaming other policy-makers for failure to uphold societal values. Recent articles, including several in this journal, have taken steps in this direction (Schimmelfennig 2001; Joachim 2003; Acharya 2004; Hawkins 2004; Carpenter 2005; Sundstrom 2005). This article seeks to augment the contributions of this research. For example, Hawkins, like Finnemore, focuses on the importance of international normative pressures in shaping state behavior (Finnemore 1996). However, as both Acharya and Sundstrom argue, international norms are less likely to be effective without domestic bases of support.

As many other scholars have found, advocates are more likely to be successful when their goals are perceived to fit with the deeply held preferences (over ends) the public and policy-makers already have. ${ }^{6}$ Boosting a norm's profile requires that champions of norms frame their arguments for successful alliance-building (Keck and Sikkink 1998:17). For a small moral interest group to succeed, what Kaufmann and Pape call a "saintly logroll," they must appeal to principles backed by the "main political factions." Moral movements, they argue, are likely to be successful the more they link their arguments to domestic reformist movements seeking to root out domestic corruption (Kaufmann and Pape 1999:663-664). While movements need to tap into the value and ideational traditions of the broader society, national role conceptions, collective ideas about the national interest, and notions of morality may also be sufficiently resonant to create winning coalitions.

Framing here is imported from the social movement literature in sociology pioneered by Mayer Zald, David Snow, Sidney Tarrow, and others. Snow defines framing as "the conscious strategic efforts by groups of people to fashion shared understandings of the world and of themselves that legitimate and motivate collective action" (McAdam, McCarthy, and Zald 1996:6). Frames serve as mental shortcuts by which policy-makers can sort information and understand the causes of a problem, its consequences, and potential solutions (Zald 1996:262). Frames help establish whether individuals can connect to cultural traditions. While policy entrepreneurs may invent new rhetoric, they typically find a repertoire of arguments

\footnotetext{
${ }^{6}$ Different terms describe this concept: grafting (Price), cultural match (Cortell/Davis, Checkel), fit (Kingdon), the nature of political discourse (Hall), resonance (Snow, Ikenberry), political culture (Risse-Kappen), legitimacy (Jacobsen), concordance (Legro), congruence (Acharya) (Snow and Benford 1988; Hall 1989:363; Jacobsen 1995:295; Kingdon 1995; Risse-Kappen 1995:188; Legro 1997:35; Checkel 1999:86; Cortell and Davis 2000:29; Price 2003; Acharya 2004).
} 
in the public arena that they can appropriate, what Jackson and Krebs call "rhetorical commonplaces" (Jackson and Krebs 2007). Nonetheless, framing is a synthetic activity rather than a purely evocative one. While advocacy groups may employ a dominant frame, they may also employ multiple messages to appeal to different groups. For example, while the dominant message of Jubilee 2000 linked the moral case for debt relief to religious morality, activists also made targeted appeals in different countries, reminding the Germans of the debt relief they benefited from after WWII and the Japanese that their leadership role was at stake.

Successful strategic framing is thus - in theory-distinguishable from more fundamental belief change and from more coercive efforts that rely mostly on shaming and political pressure. ${ }^{7}$ From this perspective, we should view framing exercises as defining situations and activating existing preferences. Policy-makers care about many things, not all of them equally. Circumstance may make a new issue salient. Salience means that an issue becomes temporally compelling to decision-makers. A politician, for example, may care about both poverty in the developing world and effective use of government resources. In the midst of a recession, the costs of foreign aid might become more important. These serial shifts in attentiveness make sense of efforts to cue emotional/moral frames and boost the salience of one dimension of a problem over another. ${ }^{8}$ The assumption is actors' basic preferences over outcomes - what they value most - are largely stable in the short-run. Preferred preferences over means - about specific policies-are less deeply rooted. Frames thus link a policy to a particular evaluative lens, facilitating shifts in support for the policy even as long-run values remain largely unchanged. ${ }^{9}$ To explain the conditions under which transnational advocacy movements' framing efforts are likely to succeed, this article focuses on how three dimensions of the "domestic political opportunity structure" — values, costs, and institutions-conjoin.

\section{The Argument - Strategic Framing/Gatekeepers}

Under what conditions will framing be successful? Payne worries that it is impossible to make a priori predictions (Payne 2001:44). This article seeks to provide a spare explanation that can assist us in explanation and prediction. Six conditions are potentially significant for framing success: (1) a permissive international context (2) focusing events (3) credible information (4) low costs (5) cultural match, and (6) supportive policy gatekeepers. This article focuses on the concatenation of the final three. The basic argument is that framing is more likely to be successful when the costs of the policies attached to them are low and the frames match the cultural values of the polities they are targeting. These are cases of cheap moral action. However, even when the policies are more costly, frames can be successful if policy gatekeepers believe the values and ideas at stake are important. These are cases of costly moral action.

\section{Permissive International Context}

As realists would argue, the international system or "political opportunity structure" can either be permissive or obstruct the acceptance of a norms-based policy (McAdam, McCarthy, and Zald 1996). A high security threat or a more generalized economic malaise may crowd out social movements and focus the attention of decision-makers on higher-order political priorities. This factor was mostly a

\footnotetext{
${ }^{7}$ In practice, it may be difficult to differentiate between situations where actors are persuaded by better arguments from actors reacting to rhetoric praising or blaming them (Hawkins 2004:783).

${ }^{8}$ Jones (1994:83). These situational redefinitions are similar to "heresthetics" (Riker 1986).

9 For a sophisticated treatment, see Fearon and Wendt (2003). This does not preclude long-run preference change, as has taken place on civil rights in the American South (Jones 1994).
} 
constant in the 1990s when material threats were low and economic circumstances for most advanced industrialized countries were generally pretty positive (with Japan a possible exception). Thus, if we were looking to make generalizations about advocacy in the 1990s, the context - including advances in telecommunications and transport - was a permissive one for all campaigns, not just debt relief. A favorable context may be neither necessary nor sufficient for successful advocacy, as the campaign for HIV/AIDS funding after 9/11 suggests.

\section{Focusing Events}

A second factor is the role of a crisis or some other focusing event that makes a problem more salient. Crises like the December 2004 tsunami or the attacks of September 11 th are examples. In the case of debt relief, the campaign's "expiration date" at the end of the millennium year concentrated attention. Regularly scheduled events like international conferences can also serve to focus attention. In those instances, an issue already on the conference agenda forces decision-makers to develop a policy (Kingdon 1995; Finnemore and Sikkink 1999). Campaigners are good at manufacturing events, taking advantage of news and venue shopping until their issues get on the agenda. Focusing events may be necessary to delegitimate an old set of ideas, but they are not sufficient to allow a new idea to become consolidated (Legro 2005:11).

\section{Credible Information}

A third factor that can enhance the work of advocates is if their claims about problems and solutions are supported by credible third-party information. Decisionmakers are likely to ask "is it true?" and "will it work?" Here, the roles of epistemic communities (scientific and technical experts), the media, and even religious figures are important (Haas 1992). ${ }^{10}$ While helpful, both successful and unsuccessful campaigns in the 1990s benefited from dedicated communities of experts. Frames that make causal claims that are known to be false should more often than not fail, but while necessary, credible information may not be sufficient to tip the political balance in favor of policy change (e.g., the climate change campaign in the United States).

A synthetic combination of three other causes - low costs, high value fit, and supportive policy gatekeepers - provides a relatively parsimonious way to explain and potentially predict successful framing. Moreover, the combination of costs, values, and gatekeepers gets inside foreign policy decision making to show that while actors have agency, they are bounded by larger societal values and the institutional context in which they operate.

\section{Low Costs}

All else equal, frames are more likely to be successful when the policy solutions attached to them are not costly. Issues championed by principled advocacy movements typically resemble public goods, where the benefits largely accrue to foreigners rather than the citizens of the nation-state. The direct benefits for the home populace are more attenuated or drawn out over time. Politicians, worried about their own electoral fortunes, have to evaluate the uncertain and long-term benefits of a policy against the more immediate costs for the country of supporting the policy. While a number of other considerations go into the metric of assessing the national interest, "how much will it cost us?" is one of the most important questions

\footnotetext{
${ }^{10}$ Callaghy argued the debt campaign succeeded because an epistemic community of debt specialists from universities, NGOs, and the IFIs developed to provide technical oversight (Callaghy 2001).
} 
policy-makers will ask. In addition, given that these problems involve coordination and bargaining between different states, decision-makers will likely assess the relative costs and ask, "what are our costs compared with others?"

\section{Cultural Match}

Even where the evidence suggests a problem exists and solutions can be effective, donor interests may remain opaque or inadequate as sufficient justification to overcome political inertia and opposition. Decision-makers cannot be sure debt relief will work as planned. The accompanying moral arguments can serve as tipbalancers to legitimate action, for those for whom self-interested justifications do not seem convincing. In other words, in addition to asking "will it work?" and "how much will it cost?" decision-makers will ask "what is the right thing to do?" There is not a unique resonant value in a given culture. Indeed, an issue can be framed in a number of ways that are consistent with the culture but that are tied to opposing policy solutions. Specific frames thus serve as focal points in strategic interactions most likely characterized by multiple equilibria. That said, this does not mean that anything goes. Frames that lack such a cultural match should be less successful because they will have insufficient appeal to generate political mobilization by citizens and/or will fail to connect with elite decision-makers directly. Unfit frames are easier to recognize in the extreme. Movements that adopt anarchist, anti-capitalist rhetoric in the United States, for example, are less likely to succeed than those that tie their arguments to religious values.

High value fit and low costs together are the most likely cases for successful framing, cases of cheap moral action. Other cases - namely ones where both costs and value fit are high - are cases of costly moral action. These are harder cases for successful framing and require integration of another factor - supportive policy gatekeepers.

\section{Policy Gatekeepers}

A country's institutional context mediates between the issue's emergence and ultimate policy outcomes, privileging some elites as they interpret the costs and values at stake. From an analytical perspective, we also have to ask, "who decides?" Policy gatekeepers are influential actors with sufficient power to block or at least delay policy change. Gatekeepers analysis is based on veto players theory but focuses more on the individuals empowered by their institutional position. ${ }^{11}$ Where there are many veto players, policy stasis becomes more likely (Tsebelis 2002:25). This establishes a higher bar for frame success as more views make it harder to please everyone. Where the literature on domestic structure relied on ideal types, veto players analysis provides a numerical index by which we can order states, potentially facilitating large- $\mathrm{N}$ analysis. Another advantage is a better representation of institutional configurations in advanced industrialized countries. For example, in the literature on domestic structure, the United Kingdom is classified as "liberal," meaning that political pressure is the most likely mechanism of policy change (Risse-Kappen 1991; Checkel 1999:88; Checkel 2001). However, in veto players analysis, the U.K. possesses few gatekeepers, making it more like statist regimes where the influence of a few individuals is important, where their beliefs and learning matter most. To identify whether or not gatekeepers are supportive, we ideally need to know their number and their preferences. Given that gatekeepers' preferences on a given issue area may be unknown in advance, the number of veto players serves as a first cut to understand the context. Large-N studies of veto

\footnotetext{
${ }^{11}$ Veto players theory is rooted in comparative politics but has been increasingly incorporated into international political economy (Vreeland 2004; Mansfield, Milner and Pevehouse 2005).
} 


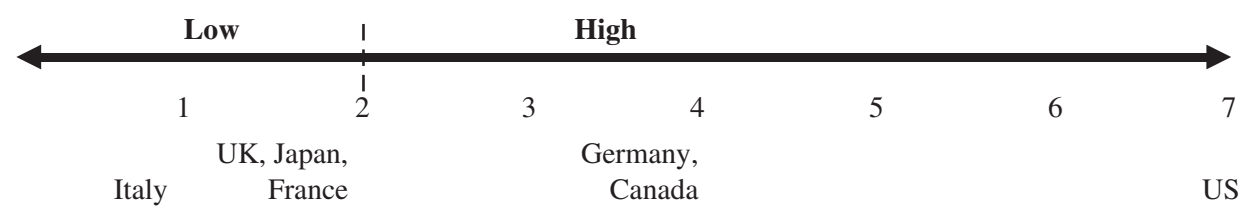

FIG. 2. Veto Players in the G-7

players often focus on institutional actors accorded influence under a country's constitution (this gets at the influence of the legislative and judicial branches) and partisan actors (this gets at the influence of political parties in divided or coalition governments) (Tsebelis 2002). Others also look to dispersion of authority, taking into account federal structures and the use of referenda (Huber and Stephens 2001:55-56). Figure 2 provides one measure of veto players. The average in 1996 for 23 OECD countries was $1.78 .^{12}$ The United States is clearly an outlier with many veto players.

However, this measure may not be sufficiently fine-grained. The datasets do not capture actors with issue-specific blocking power, namely bureaucratic actors with delegated responsibility or legislative actors with committee oversight over spending, or societal actors with informal influence (Tsebelis 2002:81). For many international issues (especially security issues), the number of veto players is truncated so the judiciary or sub-national units included in some datasets are not likely to be relevant. For treaties, countries have different rules, like the U. S. system where a two-thirds Senate majority is required for advice and consent. On debt relief, we would expect these kinds of gatekeepers based on functional delegation. In the U.K., for example, the Chancellor of the Exchequer is the dominant gatekeeper with the power to approve and fund policy relatively unencumbered by parliamentary or bureaucratic obstacles. ${ }^{13}$ The number of issue-specific gatekeepers may vary idiosyncratically depending upon the interest and stature of individuals. For example, Larry Summers wielded more influence as U.S. Treasury Secretary than his successor Paul O’Neill. With more gatekeepers, advocates will have a harder time convincing all of them. In those instances, their arguments will have to be finely tuned to the specific interests and values of the veto players, either appeals to their principled beliefs about right and wrong or their causal beliefs about the effects of different policies (Goldstein and Keohane 1993:8-9). Given such pluralism, political pressure is likely to be a more important part of policy change for issues with many gatekeepers.

\section{Background on the Empirical Case}

Debt relief for poor countries emerged as an issue in the wake of the oil price hikes of the 1970s. However, external debt problems of the poorest countries initially took a back seat to those of middle-income countries. After the Mexican government defaulted on its foreign debt in 1982, decision-makers in Western industrialized countries feared that the large exposure by private banks like Citicorp and Bank of America to middle-income countries' debts could potentially contribute to a meltdown in the international financial system (Lipson 1981). The U.S. government, most notably through the 1989 Brady Plan, moved to corral private creditors into an agreement that would ease middle-income country debt burdens and

\footnotetext{
${ }^{12}$ Data from Armingeon, Leimgruber, Beyeler and Menegale (2005). This is an additive index of five measures of constitutional structure including federalism, presidentialism, bicameralism, proportional representation, and use of referenda. For alternative measures, contact the author.

${ }^{13}$ Given U.K. Chancellor of the Exchequer Gordon Brown's support for debt relief, gatekeepers analysis reveals that the Jubilee 2000 campaign was needed least where it was strongest.
} 
prevent broader financial system instability. Concurrently, the Paris Club also began to address external debts of the poorest countries. ${ }^{14}$ However, where commercial banks had been the dominant creditors for middle-income countries, multilateral and bilateral institutions held most of poor countries' debt. As few of these countries had much access to international financial markets, dealing with poor country debts primarily had implications for the financial integrity of the multilateral lending institutions and the budgets of creditor governments. ${ }^{15}$ Beginning in 1988 with the Toronto Terms, the major creditor countries began to offer poor countries limited bilateral debt relief by way of new loans to continue payments on old loans. ${ }^{16}$

In October 1996, after years of rolling over poor country debts and providing modest debt reduction, several developed countries, the World Bank, and the IMF decided upon a joint approach for Highly Indebted Poor Countries (hereafter HIPC I). ${ }^{17}$ HIPC I incrementally increased bilateral debt reduction and broke new ground with respect to multilateral debt with the creation of a Trust Fund to pay for multilateral debt relief. HIPC also increased the level of possible bilateral debt reduction. Countries deemed eligible for debt relief reached a "decision point," and if they followed sound macroeconomic policies for several years while enjoying reduced debt payments in the interim, they would reach a "completion point" and be eligible for actual reduction of debt stock.

HIPC I, despite some influence by Oxfam and other development charities, was primarily a top-down affair. While advocates played a background role, the real change agents in this story were Kenneth Clarke, Britain's Chancellor of the Exchequer, and the World Bank's James Wolfensohn (Mallaby 2004). The main obstacle to HIPC I was the fear of "moral hazard," that definitively writing off poor country debts would reward bad behavior and encourage states to accumulate unsustainable debt burdens again (Easterly 2001). These fears were partially undercut by the recognition that these debts were unlikely to be paid back anyway, so clearing the books of bad debt was simply good accounting (Summers 2000). Moreover, economists also suggested that developing countries could experience problems of "debt overhang," where the existing stock of debt obligations was so large that private actors had a disincentive to invest in the economy, as productive investment would likely be taxed to pay off external debt obligations (Krugman 1988). At the very least, these arguments legitimated the idea that broader debt relief could potentially work.

While the story of HIPC I is largely top-down, the same cannot be said for the subject of this article, the expansion of HIPC that took place at the 1999 Cologne G-8 summit (hereafter HIPC II). Just as creditors finally reached agreement on a program to partially write off multilateral debt, NGOs were gearing up their own campaign to pursue more wide-ranging debt forgiveness in time for the new millennium. Jubilee 2000, with its explicit connection to religious traditions and the

\footnotetext{
${ }^{14}$ The Paris Club is an informal group of creditor governments, established in 1956 with a permanent secretariat in the French Treasury to coordinate policies among bilateral creditors.

${ }^{15}$ In 1997 , HIPC countries owed $\$ 201$ billion, $\$ 174$ billion in long-term debt, and $\$ 27$ billion in short-term debt. Of the long-term debt, $\$ 170$ billion was public and publicly guaranteed. Within that total, $\$ 148$ billion was owed to official creditors ( $\$ 64$ billion to the multilaterals and $\$ 84$ billion in bilateral aid) and $\$ 21$ billion to private creditors. Only $\$ 4$ billion of the total was private nonguaranteed debt (World Bank 1999a).

${ }_{16}$ Programs evolved from "Toronto terms of $33 \%$ reduction of eligible debt payments in 1988, to Naples terms of 50-67\% reduction in 1994, to HIPC terms of up to $80 \%$ in 1997" (Schuerch 1999).

${ }^{17}$ Forty-one countries were initially listed as HIPCs: 34 in Africa, four in Latin America, three in Asia, and one in the Middle East (World Bank, Undated-b). Eligibility is based on threshold indicators beyond which a country's external debt is deemed "unsustainable:" the net present value (NPV) of its debt to export ratio, the NPV debt-torevenue, and the export to GDP and revenue/GDP ratios. Debt relief is conditional upon good policy making, both macroeconomic and poverty reduction. The original list of potential HIPCs included 32 countries that had a 1993 GNP per capita of US\$695 or less and a 1993 NPV debt/exports ratio higher than $220 \%$ or an NPV debt/GNP ratio higher than $80 \%$. Nine others were included because they were eligible for Paris Club concessional lending (IMF 1998:7).
} 
coming of the new millennium, represented a "rebranding" of the debt campaigns that had been around for a number of years, according to Jamie Drummond, Jubilee 2000's former Global Strategist (Drummond 2001). Before 1994, campaigners had tried without much success to draw attention to the debt issue along with IMF- and World Bank-administered structural adjustment programs. Jubilee 2000's primary complaint about HIPC I was that it was not fast, broad or deep enough and was insufficiently attentive to basic human needs (Jubilee 2000, Undated-b).

As advocates clamored for additional debt relief, HIPC's original champion, Jim Wolfensohn, cooled to the idea, in part because it was not his (Mallaby 2004:250). Campaigners hastened awareness of the limitations of HIPC I. With debt relief under HIPC proceeding slowly, a focal point for the campaign became the G-8 Summit in Birmingham, England, in May 1998 when 50,000 campaigners ringed the summit in a human chain. The campaigners later met in Rome in November 1998 where they designed a loosely affiliated coalition of autonomous national campaigns. ${ }^{18}$ In January 1999, the Pope announced his support for debt relief. Activists meanwhile conducted high profile events with celebrities, including mass concerts, rallies, and other attention-getting actions. By July 1998, still only one country - Uganda - had reached the completion point.

Before the G-8 Summit in Germany in mid-1999, the United Kingdom, the United States, and Canada led efforts to enhance HIPC. In late 1998, newly elected Gerhard Schroeder signaled a softening in Germany's long-standing reluctance. Pressure mounted on Italy, France, and Japan to be more supportive. In March 1999, President Clinton announced a plan that established the contours for what would come out of Cologne, including front-loaded relief, increasing bilateral debt relief to $90 \%$, and additional multi-lateral financing (Clinton 1999). The plan also linked debt relief to Poverty Reduction Strategy Papers, which guaranteed that savings would be invested in education, health, and other worthy expenditures. With 30,000 protesters ringing the summit, G-7 countries in Cologne in June 1999 announced the expansion of HIPC, promising about $\$ 27$ billion in new debt reduction in net present value terms, on top of debt relief that HIPC countries were eligible for under traditional mechanisms. ${ }^{19}$

Cologne partly involved bargaining by creditors on how much each would contribute to the HIPC Trust Fund and how much bilateral debt relief they would support. The U.S. contribution was $\$ 920$ million spread out over 3 years, of which $\$ 600$ million was to be dedicated to the Trust Fund. However, this was contingent upon Congress appropriating the funds and authorizing the sale or revaluation of IMF gold (Hart 2001). The $\$ 600$ million was roughly equivalent to the EU's pledged contribution and three times that of Japan. In September 1999, President Clinton announced the United States would write off $100 \%$ of bilateral debts, followed soon by the other main creditors. U.S. funding remained in doubt until October 2000 when Congress finally appropriated $\$ 435$ million for the U.S.'s initial commitments to the HIPC Trust Fund and bilateral relief.

Through 2000, campaigners complained that the pace of debt relief was too slow and that few countries were being processed (Jubilee 2000, 2000). Continued pressure sped things up. By December 2000, 22 countries had reached the decision point and Uganda reached its completion point (World Bank 2001). Even though the Jubilee year ended, a successor campaign, Jubilee + was created to monitor the pace and breadth of implementation with calls for an independent arbitrator to take charge. Finance ministries, for their part, feared haste would compromise the

\footnotetext{
${ }^{18}$ Supporters minimally agreed there should be a (1) one-off debt cancellation (2) of the poorest countries' unpayable debts (3) by the end of the year 2000 through (4) a fair and transparent process.

${ }^{19}$ HIPC II also lowered the threshold of what were deemed sustainable debt targets including: a debt-to-export ratio of $150 \%$ down from $200 \%$ to $250 \%$, a debt-to-revenue ratio of $250 \%$ down from $280 \%$, and the export/GDP and revenue/GDP thresholds to $30 \%$ and $15 \%$ (World Bank 1999b).
} 
TABLE 1. Pledges and Shares to the HIPC Trust Fund

\begin{tabular}{lccccccc}
\hline Dollars in Millions & Canada & France & Germany & Italy & Japan & U.K. & U.S. \\
\hline Non EU-Pledges & $\$ 102$ & $\$ 21$ & $\$ 72$ & $\$ 70$ & $\$ 200$ & $\$ 221$ & $\$ 600$ \\
w/EU pledges & $\$ 102$ & $\$ 199$ & $\$ 252$ & $\$ 162$ & $\$ 200$ & $\$ 316$ & $\$ 600$ \\
$\%$ World economy & $2.15 \%$ & $4.74 \%$ & $6.99 \%$ & $3.85 \%$ & $14.55 \%$ & $4.77 \%$ & $30.16 \%$ \\
$\%$ Non-EU pledges & $5.97 \%$ & $1.23 \%$ & $4.21 \%$ & $4.10 \%$ & $11.70 \%$ & $12.93 \%$ & $35.11 \%$ \\
$\%$ w/EU pledges & $4.18 \%$ & $8.15 \%$ & $10.32 \%$ & $6.63 \%$ & $8.19 \%$ & $12.93 \%$ & $25.56 \%$ \\
\hline
\end{tabular}

quality of debt relief. As a result of depressed commodity prices, rich countries pledged in June 2002 an additional \$1 billion to "top-up" the Trust Fund. By August 2005, 18 countries had reached the completion point and had $\$ 22.1$ billion in net present value of their debts written off; another 10 had reached the decision point and were eligible for nearly $\$ 11$ billion in net present value of debt relief if they maintained sound policies. ${ }^{20}$ After the Jubilee year, many campaigners thought they had pushed the debt agenda as far it could go and initially turned to new issues like AIDS and trade. However, dissatisfaction with the pace of implementation fed renewed calls for debt relief, led by aggressive efforts by the United Kingdom and bolstered by a high-profile public campaign. In summer 2005, these efforts yielded the Multilateral Debt Relief Initiative (MDRI), a commitment by the G-8 and the IFIs to write off all of the remaining debts owed by HIPC countries to the World Bank, IMF, and the African Development Bank. Partly contingent upon financing and the eligibility criteria of poor countries, MDRI potentially means debt relief on the order of $\$ 57.5$ billion. $^{21}$

While the 2005 decision to write off most multilateral debts is historic, this article seeks to explain (1) donors' decisions to support enhanced debt relief at Cologne and (2) compliance patterns thereafter. For most of the G-7, the first decision was the significant one. Once the country's gatekeepers decided to support enhanced relief, compliance with $100 \%$ bilateral relief and their Trust Fund pledges were largely foregone conclusions. For countries with more gatekeepers, the U.S. in particular, the Cologne commitment and the pledge of $100 \%$ bilateral relief were symbolic but depended upon home appropriations. Since all of the G-7 agreed to the Cologne deal, we can track variation in behavior by looking at (1) the timing of support for $100 \%$ bilateral relief, (2) the size of the initial financial pledges donors made to the HIPC Trust Fund, and (3) how long it took them to come through on those pledges. What are these patterns? Support for $100 \%$ bilateral relief began with the U.S. in September 1999. The U.K. followed in December 1999, then Italy in February 2000, Canada in March 2000, with Germany, France, and Japan, the three most reluctant of the G-7, not announcing their support until April 2000 (Jubilee 2000, Undated-a). As for pledges to the Trust Fund, Canada, Italy, the United Kingdom, and the United States made pledges larger than their country's share of global Gross Domestic Product (GDP). French, German, and Japanese pledges are less generous by this measure (Table 1). When we include EU pledges to the Trust Fund, French and German support for the Trust Fund looks larger.

\footnotetext{
${ }^{20}$ (World Bank 2006). The eighteen HIPC completion point countries included: Benin, Bolivia, Burkina Faso, Ethiopia, Ghana, Guyana, Honduras, Madagascar, Mali, Mauritania, Mozambique, Nicaragua, Niger, Rwanda, Senegal, Tanzania, Uganda, and Zambia. In 2006, Cameroon, Malawi, and Sierra Leone became the nineteenth, twentieth, and twenty-first countries to reach the completion point. São Tomé and Príncipe became the twentysecond in March 2007.

${ }^{21}$ HIPC debt holdings by the multilaterals in 2005 included, $\$ 42.5$ billion from the World Bank, $\$ 5$ billion from the IMF, and $\$ 10$ billion from the ADB (Development Committee 2005). In 2006, four countries were deemed potentially HIPC eligible including Eritrea, Haiti, Kyrgyz Republic, and Nepal. The Inter-American Development Bank joined the other multilaterals by voting in March 2007 to write off $\$ 4.4$ billion of debts of Bolivia, Guyana, Haiti, Honduras, and Nicaragua.
} 


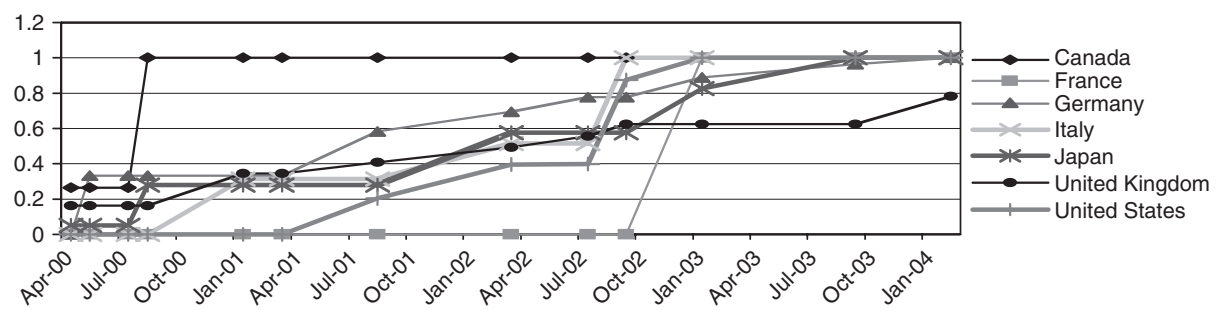

FIG. 3. G-7 Disbursements to the HIPC Trust Fund

In terms of time to compliance with their pledges (Figure 3), Canada is an outlier, completing its pledge very early. France waited nearly 3 years to make any contribution while the United States took 2 years to make its first contribution. The Germans, Italians, Japanese, and the British made early contributions but in some cases took longer than even France and the United States to reach $100 \%$ of the pledges to the Trust Fund. ${ }^{22}$

\section{A Partial Explanation-Material Interest}

Before turning to my main argument, I provide a partial explanation of these patterns based on material interest and suggest its merits and limitations. Arguments based on material interest $(M I)$ focus on the costs and benefits of debt relief. Two variants potentially explain outcomes. The first - what we can call state interest-draws on neorealist and neoliberal theories that see the state as a unitary actor responding to systemic material constraints. States should support debt relief and comply with their commitments when the benefits exceed the costs. This variant would discount the influence of advocates. Policy change from this perspective would be a product of two causal mechanisms, either: (1) simple adaptive learning (that creditors' interests would be better served by debt relief) or (2) coercion/ inducement by other states (that raise the costs of non-action). Delays in policy change could be explained as a product of collective action problems of policy coordination (Olson 1965). A second variant-individual interest-sees state behavior through decision-makers' incentives for political survival (Bueno de Mesquita, Smith, Siverson and Morrow 2003). In this view, politicians support policy change when it is (1) politically advantageous or (2) politically costly to fail to do so. This pluralist account is familiar. Research that incorporates domestic structure argues that liberal polities — like the U.S. — are typically moved by bottoms-up pressure. A movement's relative political strength - as measured by membership, resources, protests, and its ability to leverage coercive influences, domestic and foreign - would determine its success or failure. ${ }^{23}$

In 1996, when the HIPC initiative was created, creditors recognized additional debt relief was warranted. At the same time, they wanted to retain elements of conditionality to prevent debtors from returning to bad practices. Jubilee 2000, by contrast, wanted complete and unconditional debt relief. While some individuals in creditor countries were supportive of additional debt reduction beyond HIPC I, states like Japan and Germany and important players within other creditor

\footnotetext{
22 The Germans, Italians, and Japanese met $100 \%$ of their pledges by February 2004, September 2002, and September 2003, respectively, while France and the United States met theirs by January 2003. The U.K.'s apparent lag in Trust Fund contributions is explained by legislation that prevents funds from being disbursed without an assurance that they can be spent within three months (Jenns 2006). The figure does not include other U.K. contributions to the Trust Fund for Ugandan debt relief. Data on pledges and disbursement to the Trust Fund come from periodic HIPC Status of Implementation reports (World Bank, Undated-a). Economic data on the G-7 come from the World Economic Outlook (IMF 2005).

23 "Mobilizing resources" in the social movement literature (McAdam, McCarthy and Zald 1996).
} 
TABLE 2. G-7 Debt Holdings Circa 1998-1999

\begin{tabular}{lccccccc}
\hline Dollars in Millions & Canada & France & Germany & Italy & Japan & U.K. & U.S. \\
\hline Bilateral claim-40 countries & $\$ 711$ & $\$ 13,033$ & $\$ 6,586$ & $\$ 4,311$ & $\$ 11,200$ & $\$ 3,092$ & $\$ 6,210$ \\
As \% of GDP & $0.1 \%$ & $0.9 \%$ & $0.3 \%$ & $0.4 \%$ & $0.3 \%$ & $0.2 \%$ & $0.08 \%$ \\
As \% of G-7 claims & $1.57 \%$ & $28.9 \%$ & $14.6 \%$ & $9.5 \%$ & $24.8 \%$ & $6.8 \%$ & $13.8 \%$ \\
\hline
\end{tabular}

countries did not think that expanding HIPC was a good idea. Indeed, HIPC I did not have much time to be implemented so revisiting the agreement was not the highest priority from a state interest perspective. What about the costs and benefits of debt relief? As depicted in Table 2, the main creditors - the G-7-had different levels of bilateral (country-to-country) debts. They also made different promises to underwrite debt relief for money owed to multilateral financial institutions (with the Europeans double-giving through the EU). Donors also had different accounting rules that affected their actual costs of debt relief (some already having provisioned for bad debts). ${ }^{24}$

The patterns here provide some support for MI. Some states, namely, Japan, Italy, and Germany (before the Schroeder era) were strongly against debt relief, and other creditors had to make repeated attempts to get them to change their policies. Given that the laggards - France and Japan — had the largest outstanding bilateral debt, their initial opposition to debt relief seems consistent with MI. Since Britain and Canada - the leaders - were the smallest holders of bilateral debts, one could also explain their enthusiasm accordingly. The timing of Italian and German support for debt relief (i.e., following the leaders) is also consistent with their debt holdings. However, the compliance patterns are less clear. While the costs of debt relief for the United States were small, it took a long time to fulfill its pledge to the HIPC Trust Fund. Japan faced high costs of debt relief, but it began to comply with its commitments faster than either France or the United States.

Like debt levels, coordination problems over burden sharing also provide a partial answer for why getting an agreement proved difficult. If creditors want to give poor countries a fresh start, not only must multilateral debt be forgiven, but each bilateral member has to be convinced to write off its debt. However, if the United States, for example, wrote off its bilateral debt, then other donors might be more likely to be repaid at its expense. ${ }^{25}$ In the absence of a coordinating mechanism, no country will have an incentive to forgive its debts unilaterally. While one might expect that international financial institutions (IFIs) can help resolve these collective action problems, the IFIs have their own disincentives to cooperate. The IFIs fear moral hazard, and the loans from multilaterals are spread among them. Being the first to forgive debt would mean other creditors would more likely be paid off. Ultimately, the IFIs depend upon member governments for support so these institutions become forums for those distributional battles. Serieux and Samy argue the insignificance of poor debtors for international financial stability, coupled with coordination problems, delayed the response and created the need for a movement to break the impasse (Serieux and Samy 2003:4). Debt levels suggest why some states were more enthusiastic than others, and coordination problems help us understand the delay. Neither, however, explains why a new agreement was reached in 1999.

Individual interest arguments offer another possible mechanism. In this view, campaigners made it politically costly for actors to ignore their concerns. Indeed, one cynical version of this argument suggests promises of debt relief provided

\footnotetext{
${ }^{24}$ (GAO 2000). Japanese and French costs were about $\$ 8$ billion each as neither had done much provisioning for bad debts. U.S. costs were about $\$ 3.7$ billion due to provisioning for bad loans. Costs for HIPC have risen with the inclusion of new debtors and topping up to account for commodity price shocks.

${ }^{25}$ This idea of Paul Krugman's is related to commercial debt in Crook (1991).
} 
politicians with cheap public relations gains. Leaders have either failed to implement debt relief or have used it as a substitute for other forms of foreign assistance (Arslanalp and Henry 2006). As the empirical section demonstrates, lobbying by campaigners is one of the mechanisms that put this issue on the agenda. However, the G-8 protests aside, the campaign was only able to bring modest pressure to bear in different national contexts. In the United States, for example, the national rally campaigners organized in April 2000 was attended by 6,000 people, hardly comparable with the hundreds of thousands that participate in marches against hot-button issues like abortion. While celebrity participation enhanced the visibility of the campaign, Bono himself acknowledged, "... in the United States, Jubilee 2000 had been a lot slower to catch on. We were running out of time to grow the grassroots. I had to go straight to the decision-makers ..." (Bono and Assayas 2005:89). Former Treasury Secretary Larry Summers made a similar observation, "We could have not done it, and it wouldn't have been a political disaster" (Summers 2004).

As for the claim that debt relief represents public relations window-dressing, as of March 2007, 22 countries have reached the HIPC "completion point" and are thus eligible for more than $\$ 24.5$ billion in debt stock reduction. The World Bank estimated that the ratio of debt service to government revenue for HIPC countries has fallen from $23.5 \%$ in 1998-1999 to $11.7 \%$ in 2005, which has freed up resources for investments in health, education, and other sectors (World Bank 2006:28). Moreover, contrary to claims of aid substitution, G-7 donors, in the period 19992004, collectively increased their nondebt relief foreign assistance to HIPCs by $37 \% .^{26}$ Thus, while both state and individual interest arguments provide a partial understanding of donors' willingness to support debt relief, an expanded agreement on debt in 1999 was not inevitable nor was the emergence of Jubilee 2000 structurally determined. An analysis that failed to reflect advocates' efforts, including their moral claims, would tell us little about how states and key leaders came to support expanded debt relief in HIPC II.

\section{A More Complete Explanation-Strategic Framing/Policy Gatekeepers}

What value-added does a strategic framing/gatekeepers argument have? There are four observable implications. While acknowledging advocates are (1) most likely to succeed when there are low costs, cultural match, and supportive gatekeepers, a strategic framing argument would also recognize (2) possibilities for costly moral action where gatekeepers believe the values at stake are important. Where there are many gatekeepers, (3) advocates will have to make more arguments to bring them all on board. Finally, we should (4) not be able to identify clear overwhelming material pressures supporting the decision. If we observe such pressures, it would be impossible to detect if framing matters. To lay bare differences between strategic framing and MI, we can look at the intersection of costs and values in a two-by-two matrix and then look for indicators of costs and values to map the country cases. Policy solutions attached to frames can have high or low costs. A frame may have high or low fit with a country's values. Table 3 allows us to classify cases and make predictions about which dynamics ought to predominate.

In Cell 1, the policy is not costly to support and the frame is consistent with the country's values. These are cases of "cheap moral action." Cell 1 represents the most likely cases for successful framing. These are cases where MI would also predict states will embrace a new policy. Cells 2 and 3 depend on the position of policy gatekeepers. In Cell 3, low value-fit and low costs should make a state

\footnotetext{
${ }^{26}$ Large increases in U.S. aid largely drove this result. The United Kingdom and Canada also increased their aid while the other donors had flat or slight decreases in their nondebt relief foreign aid (OECD 2006).
} 
TABLE 3. Matrix of Costs and Values

\begin{tabular}{lll}
\hline \multirow{2}{*}{ Values } & \multicolumn{2}{c}{ Costs } \\
\cline { 2 - 3 } How fosts & \multicolumn{1}{c}{ High Costs } \\
\hline High fit & Low costs, high fit & Cheap moral action \\
& Values win (1) & $\begin{array}{l}\text { High costs, high fit } \\
\text { Costly moral action } \\
\text { Gatekeepers (2) }\end{array}$ \\
\hline Low fit & Low costs, low fit & $\begin{array}{l}\text { High costs, low fit } \\
\text { Indifference } \\
\text { Gatekeepers (3) }\end{array}$ \\
\hline
\end{tabular}

"indifferent" to accepting the new policy. Because the stakes are low, interested policy-makers may support a policy in the absence of compelling material or moral reasons. In Cell 2, costs and values are misaligned. While values are supportive, short-run costs are not. MI would generally say cost concerns should trump values, unless coercion alters the cost/benefit calculus or long-run benefits clearly warrant short-run pain (Axelrod 1984). Strategic framing recognizes there may be cases - as in the British position against the slave trade - of states engaging in what Kaufmann and Pape call "costly moral action" (Kaufmann and Pape 1999). Under what conditions might states engage in costly moral action, Cell 2? Here, the role of policy gatekeepers becomes critical. If the country's gatekeepers believe the values at stake are important enough, then opposition due to high costs may be overcome. Where there are many gatekeepers, it will prove difficult to satisfy them all simultaneously. Whether gatekeepers are supportive depends on their own assessment of the relative importance of costs and fit with their values. These are critical, tough cases for strategic framing as MI makes a different prediction. Finally, in Cell 4, there are high costs, but the way the issue has been framed does not resonate with the country's culture. Therefore, we should observe that a materialist calculus dominates and thus "hostility" best describes the probable country position. The country will oppose the policy unless countervailing power coerces them or the issue is reframed to appeal to a different set of values to move the issue from Cell 4 to Cell 2.

Before fully integrating an analysis of gatekeepers, Table 3 can serve heuristic purposes for case selection and prediction. By documenting potential costs and the frame's value fit, country cases can be mapped in a two-dimensional space. Tracking costs and values is complex. There are a variety of different potential indicators that could be used, and defining thresholds between high and low is tricky. The previous sections presented some indicators of costs. As Tables 1 and 2 showed, G-7 countries varied in their bilateral debt holdings and their pledges to the HIPC Trust Fund. They also vary in the size of their economies, so debt write-off for one might be a lot in aggregate terms but a small percentage of GDP. As a percent of GDP, even the extreme cases are modest (0.9\% France, 0.3\% Japan). However, setting these costs against the backdrop of GDP may be misleading. Judgments of relative costs tend to be domain-specific. Leaving aside the costs of multilateral relief, some countries potentially bore more of the burden of bilateral relief. Even if total costs are modest, donors are likely to be sensitive that their own country is bearing a disproportionate share of the costs. Japan and France, for example, accounted for more than 53\% of the total G-7 holdings. Moreover, debt relief potentially competed with other foreign assistance programs for funds. Thus, bureaucratic actors charged with development assistance could have had a large portion of their budget precommitted, limiting discretion for other purposes. Finally, the monetary costs of debt relief might pale in comparison with the political 
TABLE 4. G-7 Measures of Religiosity

\begin{tabular}{lcccccccr}
\hline$\%$ & Canada & France & \multicolumn{2}{c}{ Germany } & Italy & Japan & U.K. & U.S. \\
\hline Are you religious? & 73.37 & 49.97 & W 63.68 & E 31.27 & 84.63 & 26.02 & 51.5 & 82.5 \\
\hline
\end{tabular}

costs. Foreign aid, for example, is a small part of the U.S. budget, yet it can be politically costly to support. ${ }^{27}$

As for values, there are a number of different ways to get at this question. The debt relief effort in 2000 was primarily framed in religious terms. Thus, one way to assess the potential cultural resonance of the frame is to look at attitudes toward religion. As values are supposed to be relatively long lived, I look at average religiosity across the four waves of data from the World Values Survey dating back to the 1980s. ${ }^{28}$ The higher the religiosity, the greater the likelihood the public can be mobilized on that basis. As Table 4 shows, the United States, Italy, and Canada are more religious than other G-7 countries. East Germany, having recently emerged from communism, is much less religious than West Germany. The Japanese are the least religious (and have a different tradition) which helps explain the country's initial reluctance to support debt relief. Like Japan, France never developed a strong debt movement, perhaps linked to its anticlerical past.

What does the mapping of costs and values reveal? In Figure 4, the G-7 share of bilateral debts and religiosity scores are plotted in two-dimensional space. Anything above $50 \%$ religiosity is coded as "high" value fit with the religious frame. ${ }^{29}$ The threshold for "high" costs is defined as anything above the mean share of bilateral debts $(14.3 \%)$. This threshold is based on how decision-makers thought about the problem, in terms of the domain ("as foreign aid, was this costly?") and in terms of the relative costs ("who bears the burden?"). Looking at relative G-7 debt holdings is useful because it gets at the differences in the potential political costs of supporting debt relief. The precise threshold between high and low costs may be less important than the general patterns observed.

On this representation, four cases (Canada, Italy, the United States, and the United Kingdom) were cases of cheap moral action in Cell 1. Two cases, France and Japan, were cases of hostility, of high costs and low value-fit. One country, Germany, was a case of costly moral action, with both high costs and high value-fit.

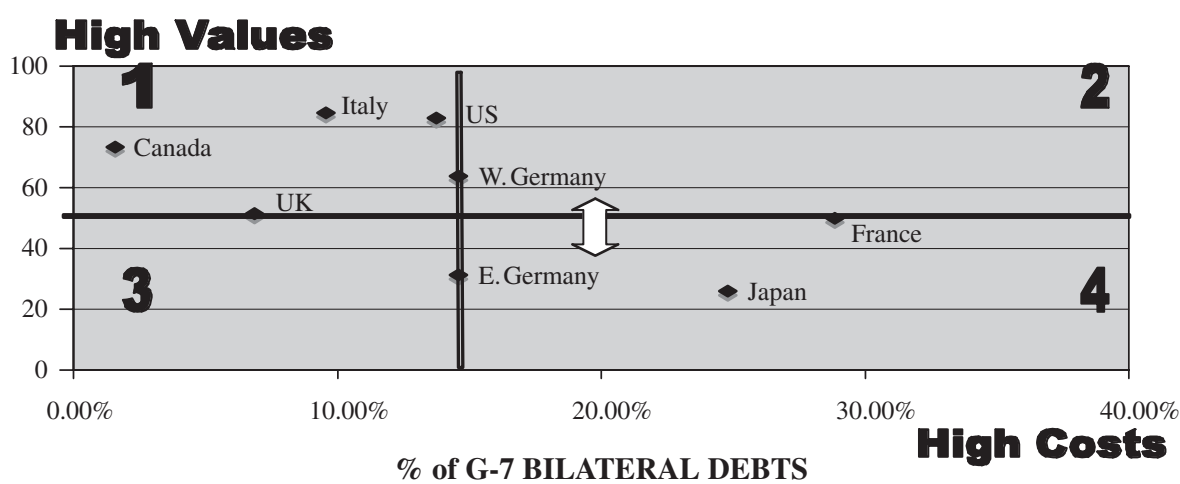

FIG. 4. Mapping of Bilateral Debt Burdens and Religiosity

\footnotetext{
${ }^{27}$ Larry Summers thought $\$ 435$ million for debt relief in 2000 was "a big amount," noting that many foreign aid expenditures start out in the $\$ 20$ million range (Summers 2004).

${ }^{28}$ People were asked "are you religious?" (Inglehart 2005). The four waves of surveys were taken in 1981, 19901991, 1995-1998, and 1999-2001. Except for British attitudes on religion, values were very consistent across waves. For other indicators, contact the author.

${ }^{29}$ The arrow between East and West Germany reflects shared debt holdings but different religiosity.
} 
TABle 5. Costs/Values, Veto Players, and Advocacy Success

\begin{tabular}{|c|c|c|}
\hline Low Likelihood & $\longrightarrow$ & High Likelihood \\
\hline $\begin{array}{l}\text { Hostility }+ \text { high veto } \\
\quad \text { (Japan, France })\end{array}$ & Indifference + high veto & $\begin{array}{c}\text { Cheap moral action }+ \text { low veto } \\
\text { (U.K., Italy) }\end{array}$ \\
\hline Hostility + low veto & $\begin{array}{c}\text { Cheap moral action }+ \text { high veto } \\
\text { (U.S., Canada) }\end{array}$ & Indifference + low veto \\
\hline $\begin{array}{c}\text { Costly moral action }+ \text { high } \\
\text { veto (Germany) }\end{array}$ & Costly moral action + low veto & \\
\hline Coercion & < & Conversion \\
\hline
\end{tabular}

When we look at the religiosity of most G-7 countries, there is a fount of religious belief that served the campaign well in even more secular countries like the United Kingdom. At the G-8 meetings in Birmingham and Cologne, the majority of protesters were from church groups and church-linked charities. Similarly, faith groups were the main supporters in the United States, where local clergy encouraged members to contact their legislators. The religious symbolism, coupled with the timing of the new millennium, was such that the campaign was able to attract a wide swath of support from North and South, left and right. Whereas there was a tendency for radical elements to bash capitalism as in the 1999 WTO protests in Seattle, Jubilee 2000 brought on board influential supporters from the entire ideological spectrum as well as ordinary citizens, what Drummond called "establishment taxpayers" (Drummond 2001). Debts were also rhetorically linked to cuts in education and health care and, in turn, death, malnourishment, and poverty, particularly among children. This helped recast the issue from fear of corruption to one of morality and justice: "[T] he intellectual argument in favor of debt relief has largely been won - few countries argue any more that relief will by itself create large moral hazard problems ..." (Beattie 2000). As The Guardian concluded, "Yes, Jubilee 2000 had successfully shifted the development agenda from one of charity - of the 'poor little things they don't have enough to eat' variety - to one of justice" (Apocalyptic in America 1999). The Washington Post's Sebastian Mallaby concurred, saying: "Late last year, during the endgame of the budget fight, the Republican line was that aid would drain money from Social Security; it was a choice of 'Ghana vs. Grandma,' they exclaimed, ridiculously. But you don't hear that so much now" (Mallaby 2000).

While Figure 4 provides a representation of cost and values, the role of gatekeepers complicates the so-called easy cases in Cell 1. Table 5 presents predictions for the likelihood of successful framing when we combine the measure for costs and values with a dichotomous value for the number of gatekeepers. The third row combines this with the "Coercion-Conversion" continuum, suggesting that as you move from left to right, the mechanisms advocates must rely on to induce policy change can be less coercive. The table also includes measures of veto players from Figure 2 and demonstrates that the United States and Canadian cases were harder cases for successful framing because of this institutional dimension. ${ }^{30}$

The depiction thus far is of costs and values being the most salient points of division. There may be situations of values versus values or norms clashing with other norms. Typically, these are situations where international norms face opposing domestic norms. Scholars assessing those cases find international norms succeed when powerful states coerce or socialize weaker ones to accept them (Ikenberry and Kupchan 1990; Farrell 2001). Another view suggests international

\footnotetext{
${ }^{30}$ As the data were based on whole numbers and the OECD average was 1.78 , two or more veto players is coded as "high."
} 
norms may gain traction after foreign pressure and crises delegitimate domestic norms and create space for actors to claim the new ideas serve the national interest (Cortell and Davis 2005). In these explanations, material incentives-foreign pressure, self-interest, and local lobbying - resolve which norms win. Thus, the material-ideational cleavage of Table 3 is still the best way to capture case dynamics. However, when two norms that both have domestic support clash and are the primary source of contention, then this is akin to Cell 2 of costly moral action. In those instances, which idea wins may not be a product of overwhelming material incentives but be resolved by gatekeepers. For example, in the case of debt relief, one could argue that concerns about moral hazard constituted a rival idea to the normative agenda of Jubilee 2000. The religious appeal of Jubilee 2000 gave debt relief a plausible cultural match at the societal level in a number of countries, but debt relief also had to dislodge moral hazard and survive the scrutiny of veto players. Fortunately for advocates, moral hazard had already been partially delegitimated as an overarching concern, in part by creditors' initial acceptance of broader debt relief in 1996, but also as networks of experts provided credible information that external debts were preventing countries from getting their finances in order.

\title{
Causal Processes in the United States and Japan
}

We can get leverage on the relationship between costs, values, and gatekeepers by looking at two creditors in more detail - the United States and Japan. What justifies studying them? By looking at an easy case (the United States) and a hard case (Japan), we can better understand the mechanism by which framing can connect to ideational currents in different national contexts with distinct institutions and decision-making processes. The United States case is closer to Cell 1, a case of "cheap moral action." It is a critical case for strategic framing in that if the causal mechanism does not apply in this easier case, the theory is unlikely to have explanatory power in harder cases. ${ }^{31}$ Moreover, when we add in the institutional dimension of policy gatekeepers, the case looks more puzzling. Jamie McCormick, former committee staff member to Congressman Jim Leach - the lead sponsor of a House bill on debt relief- got at the political difficulties for debt relief in Congress:

\begin{abstract}
One of the reasons I was so stunned that the whole debt relief initiative took off is that the campaign seemed to fly in the face of so much the new and more conservative Republican House caucus/leadership stood for. After all, this all came about shortly after the contract for America, pledges to cut foreign aid, eliminate the Commerce Department, downsize the State Department ... (McCormick 2005).
\end{abstract}

The United States was experiencing divided government between Democrats in the Executive Branch and a Republican-controlled Congress. The president was weakened by scandal. At a time of heightened isolationism, debt relief was one instance when campaigners were able to induce the United States to support a new multilateral initiative. President Clinton's difficulties in getting appropriations for debt relief continued patterns of conflict over foreign policy like the deadlock between the Clinton administration and Senator Helms over UN funding. For those interested in what it takes to move the world's most powerful nation, debt relief can shed light on other areas. The coalition of liberal Democrats and conservative Republicans that came together on debt has had a lasting impact on other issues, namely, HIV/AIDS. The Japanese case is a harder case for framing. The costs of debt relief were higher for Japan, and the initial religious frame did not enjoy local cultural

${ }^{31}$ For a discussion of most likely cases as critical cases, see George and Bennett (2005:121-122). 
resonance. However, if we can find support for framing and gatekeepers theory to be operative in this tough case, we can have more confidence of broader generalizability of the argument.

\section{The United States}

For most issues, the U.S. possesses many policy gatekeepers, and debt relief was no exception. In addition to the president and treasury secretary, a number of Congressional committees and subcommittees also had jurisdiction including House and Senate Banking (chaired by Jim Leach and Phil Gramm, respectively), a House Appropriations subcommittee (chaired by Sonny Callahan), a House Banking subcommittee (chaired by Spencer Bachus), Senate Foreign Relations (chaired by Jesse Helms), and House Budget (chaired by John Kasich). ${ }^{32}$ The large numbers of players involved in foreign aid and appropriations complicated the Executive Branch's pledges. With more gatekeepers, we would expect that more arguments would be needed to persuade them and that political pressure would be among the mechanisms that shifted lawmakers. After Cologne, other countries hesitated fulfilling their commitments as long as the U.S. contribution remained in doubt. On September 29, 1999 Clinton agreed to cancel $100 \%$ of bilateral debts but had yet to secure funding. Not until October 2000 was Clinton able to secure a $\$ 435$ million appropriation, which included the United States's first (and critical) contribution to the HIPC Trust Fund. How were the key policy gatekeepers-Summers, Kasich, Leach, Bachus, Callahan, Helms, and Gramm-convinced to support (or drop their opposition to) debt relief?

Though interest-based arguments help explain the outcome, they alone are not determinative. Part of the explanation lies in the actions of advocates who influenced policy-makers through (1) appeals to causal beliefs, (2) appeals to religious morality, and (3) political pressure. Between 1997 and 2000, debt relief advocacy in the United States would go from being un-influential to a small, robust movement. In the 1980s and early 1990s, advocates had pushed debt relief through the Debt Crisis Network (1985-1990) and a later Debt Action Coalition (1991-1993). Formed by development NGOs and religious groups, both dissolved in part because activists could not find a suitable "handle" to influence policy-makers (Donnelly, Undated). In April 1997, meetings between British activists and a religious working group on the IMF/World Bank led to the launch of Jubilee 2000/U.S.A. ${ }^{33}$ Other elements were the Catholic reform church and the mainline Protestant denominations. Both had strong connections to developing countries through missionary activities.

Because the United States development advocacy sector is smaller than the United Kingdom, there was no large mass movement to generate political pressure. ${ }^{34}$ Nonetheless, the religious frame resonated with churchgoers. Members of Congress began to get mail, phone calls, and visits in their districts in small but significant numbers. Campaigners like Bono inductively learned the importance of connecting directly with gatekeepers. Realizing that Clinton's support would not be enough, Bono's guiding questions for lobbying became, "Who can stop this from happening?" and "Who's the Elvis here?" (Bono and Assayas 2005:91). Advocates began to cultivate ties with Republican committee chairs and build support

\footnotetext{
${ }^{32}$ Other executive branch actors with minor influence included the Office of Management and Budget, the Council of Economic Advisors, and the State Department.

${ }^{33}$ The IMF/World Bank Working Group included groups like the 50 Years is Enough, U.S. Network for Global Economic Justice, the Maryknoll Office for Global Concerns, the Africa Faith and Justice Network, the Columban Justice and Peace Office among several others.

${ }^{34}$ While major charities like CARE are based in the United States, there are few development advocacy organizations, Oxfam U.S.A. and Bread for the World being the most prominent. Newer groups include Bono's DATA (Debt Aid Trade Africa). Contact the author for comparative data.
} 
from unlikely quarters. After the President's announcement, Bono came to the United States and made links with the Administration, including Larry Summers and members of Congress. Bono, through the Shrivers, was introduced to Arnold Schwarzenegger who counseled him to link up with Republicans such as Representative John Kasich, chair of the House Budget Committee. Kasich in turn brokered meetings for Bono with other Republicans including Orrin Hatch, Dennis Hastert, and Dick Armey (Peterson 2001).

Given the large number of gatekeepers, advocates developed multiple arguments to appeal to them. Adrian Lovett, former Deputy Director of Jubilee 2000 and later Campaigns Director for Oxfam, noted that for Treasury officials and those with more of a focus on technical aspects of finance, one could argue that these were bad debts that were not going to be repaid. The spiritual idea was another. A third argument was that America had a chance to change its international image. One of those arguments typically worked (Lovett 2003).

In March 1999, Clinton's plan for an enhanced HIPC initiative was announced in the run up to Cologne. At the same time, U.S. campaigners like Tom Hart, Director of Government Relations for the Episcopal Church, had formed a lobby group. They approached Congressman Jim Leach, a moderate Iowa Republican, chair of the House Banking and Financial Services Committee. Leach agreed to introduce a debt relief bill, H.R. 1095, on March 11, 1999, just days before Clinton announced his plan. By approaching a Republican committee chair, campaigners made what proved to be an excellent tactical move to broaden their base of support. In the meantime, campaigners, particularly from Bread for the World, had encouraged members of Congress to co-sponsor the bill. Grassroots efforts by religious groups in the Midwest and the South made in-roads. One success was Spencer Bachus, an Alabama Republican known for being a "conservative's conservative" who became one of the bill's strongest supporters (Grunwald 1999). Bachus, as chair of the House Banking Subcommittee on Domestic and International Monetary Policy, could have blocked consideration of the bill. Conservatives like Bachus attracted attention because it was so unexpected.

Three prominent actors - Larry Summers, John Kasich, and Jim Leach-were all persuaded debt relief was the right thing to do based on technocratic ideas. While Treasury had concerns debt relief would cut poor countries off from capital markets, Larry Summers (who succeeded Robert Rubin as Secretary of the Treasury in June 1999) ultimately recognized those countries were unlikely to be getting much access. Moreover, in Summers' view, there was no good reason to maintain the pretense that these countries were creditworthy. Continuing defensive lending so countries could payoff old loans with new loans was "phony." Because these debts were not going to be paid anyway, this was sound financial practice to write them off (Summers 2004). Like Summers, John Kasich found this appealing. According to Scott Hatch, a former GOP leadership staffer and confidante of Kasich, the Congressman responded because he thought debt relief was a viable way to free up resources for poor countries to spend on education and health care (Hatch 2005). Jim Leach's support was motivated by a similar dynamic. Jamie McCormick, former staff to Leach's committee, suggested the Congressman thought debt relief was the right thing to do, noting that Leach came at the issue more from a financial perspective than a religious one (McCormick 2005). However, this argument was not sufficient to generate a majority coalition for debt relief. $^{35}$

The religious case for debt relief had direct appeal to important individual lawmakers and also created some measure of political mobilization that pressured

\footnotetext{
${ }^{35}$ Evidence of this is the 216-211 vote in July 2000 for an amendment that boosted the HIPC Trust Fund appropriation by $\$ 155$ million. It passed only with 26 crossover Republican votes including a number of religious conservatives-Aderholt, Bachus, Cubin, Ehlers, English, Smith - NJ, and Wolf.
} 
skeptics. Aside from activists and leaders like Pat Roberston, prominent Congressional Republicans - Spencer Bachus and Jesse Helms in particular - found the religious message compelling. ${ }^{36}$ Asked about his position, Bachus said, "This bill is a gift of life. Jubilee 2000 is a celebration of the 2000th birthday of Christ .... What more appropriate time to give to these poor in celebration of the birth of Jesus, who gave us life?" (McManus 1999). Hart suggested legislators like Bachus were amenable to the message of Jubilee because it came from people with deep roots in local institutions (Hart 2001). Like Bachus, Helms was moved by his faith. Mark Lagon, former senior staff to the Senate Foreign Relations Committee under Helms, suggested the Senator had been reached by Christian conservatives before his meeting with Bono. That meeting left Helms a "bit choked up about children in need" even as he insisted that debt relief not end up supporting corruption (Lagon 2005). Why had not Helms and others experienced this epiphany earlier? Part of the story is about agency by advocates. The appeal to them on religious grounds had not been done. Helms' support was not foreordained, but an appeal based on religious morality was more likely to succeed in the United States than less religious places, particularly among lawmakers like Helms who had a record of policy decisions guided by moral concerns.

How did these gatekeepers then exercise influence over their peers? Hatch argued that Kasich's influence was less based on his role as a committee chair and more informal, that he was able to use "political muscle" and "personal credibility" with his Republican colleagues as a fiscal hawk and solid conservative to get debt relief through the House (Hatch 2005). Like Kasich, Helms' influence on this question was more informal. Lagon said the "striking thing" about Senator Helms' support for debt relief was that "it left people with the idea "Oh well, if Helms thinks this is okay, it must be the right thing to do." "It was certainly, "hard to be outflanked on the right." In Lagon's view, Helms' support could potentially sway up to 25 of the most conservative and purest free-marketeers in the Senate (Lagon 2005). In sum, their acceptance of new causal and principled beliefs about the efficacy and legitimacy of debt relief gave their Congressional allies, who knew little about the issue, the confidence that the measure was worthy of support.

Gatekeepers that remained opposed to debt relief-Sonny Callahan and Phil Gramm - appear to have been moved by political pressure, lobbying, and shaming. In the weeks before the October 2000 vote, Pat Robertson asked Texas viewers of the 700 Club to "let Senator Gramm know that this is a good initiative" (Hoover 2001). Another pressure was a threat of a presidential veto of the budget. Summers likened the bargaining process over the Omnibus appropriations bill in fall 2000 to a "game of chicken." For opponents, the specter of a veto forced them to ask: did they want to be known for denying education spending just to prevent spending on debt relief? (Summers 2004). Callahan argued that given the ubiquity of veto threats that he "never paid much attention to that." He did not object to debt relief but worried that without "contingencies" states would return to their bad behavior. He acknowledged the role of lobbying pressure, "All I did was make a little fuss over it and I incurred the wrath of the church community worldwide." Callahan suggested he and other members of Congress were ultimately responsive because they were getting a lot of flak in their districts from the church community. "I was always swimming upstream," Callahan said, "but I had a powerful enough oar to delay" the appropriation for foreign operations "against the will of a majority of Congress." Realizing supporters had the votes to amend the appropriations bill on the floor, Callahan let the appropriation for debt relief go forward (Callahan 2005). As Callahan admitted, "The debt relief issue is now a speeding train.

\footnotetext{
${ }^{36}$ On the broader mobilization of religious conservatives on international issues, see Hertzke (2004).
} 
We've got the pope and every missionary in the world involved in this thing, and they persuaded just about everyone here that this is the noble thing to do" (Kahn 2000). So, while moral reasons motivated many supporters, opponents found themselves subject to the piety of their peers, evidence that a well-chosen frame can elicit the semi-coercive pressures of social shaming in the absence of a well-financed campaign.

\section{Japan}

The original religious appeal of Jubilee 2000 lacked local cultural foundations in Japan, and the costs of debt relief, while a small share of GDP, were much larger than for other G-7 countries. Thus, Japan represented a case of "hostility" in which we would not expect advocates to be successful unless Japan was coerced or the issue was reframed to appeal to a different set of values. Reframing the issue as a test of Japan's international contribution proved compelling.

While the Japanese public was generally supportive of foreign aid, the government, particularly in the Finance Ministry - the dominant gatekeeper - found debt relief inimical. Where did these views come from? In the 1980s, the U.S. feared the Japanese would overtake them as global leaders and pressured the Japanese to share the leadership burden. Given constitutional restrictions on playing a military role, the Japanese sought to satisfy these concerns by becoming the biggest provider of foreign assistance, building on their experience in East Asia. As Yasutomo argued, "ODA [Overseas Development Assistance] is considered a key to Japan's status and survival as an accepted member of the world community" (Yasutomo 1995:3-6). By the late 1990s, the international political environment had changed, with persistent poverty, particularly in sub-Saharan Africa, motivating debt forgiveness. Given their own experience in East Asia, the Japanese were very uneasy with debt relief. They worried that debt relief would damage the "credit culture" and cut developing countries off from access to capital markets. They believed that their ODA loans had been indispensable tools that built much of the needed infrastructure and contributed to the long-term growth and development of Malaysia, Thailand, Korea, and other Asian countries (Japanese MOFA official 2004).

While Japan signed on to the enhanced debt relief program at Cologne, it remained unenthusiastic about complete bilateral relief. In the lead up to the Okinawa G-8 meetings in July 2000, Japan announced it would accept $100 \%$ bilateral relief. ${ }^{37}$ Why did Japan change its policies? The argument was recast by activists and other creditor governments as something Japan could do to be a solid contributor to the international community. As Marc Castellano of the Japanese Economic Institute put it: "The country's reputation as a global leader also is on the line" (Castellano 2000). Henry Northover, of the United Kingdom-based Catholic charity CAFOD, argued that the Japanese were not going to stand out against the majority within the G-7. His sense was that the Japanese see themselves as responsible members of the international community and were loath to step out (Northover 2003). This interpretation of Japanese policy is supported by interviews with Japanese officials. Takehiko Nakao, Director of the Coordination Division in the Ministry of Finance's International Bureau, provides an authoritative account. ${ }^{38}$ Japan, Nakao said, appreciated that other G-7 countries supported debt relief. If all G-7 countries support an initiative, Japan tends to support them. Nakao

\footnotetext{
${ }^{37}$ Continuing a practice dating back to 1978, Japan initially decided in 2000 that it would reimburse debt service in the form of grants. In December 2002, the government announced that the Japan Bank of International Cooperation (JBIC) would cancel all ODA debts of eligible HIPCs by using the bank's surpluses that had improved as East Asian countries repaid their loans (Nakao 2004).

${ }^{38}$ From 2002 until July 2004, Nakao served as Director of Development Policy and was Japan's head delegate to the Paris Club. From 1998-2000, he was Director of International Organizations, charged with oversight of G-7 Summits and the IMF.
} 
said that Japan puts a lot of importance on G-7 summits, the UN General Assembly, and the OECD. While the United States-Japan bilateral security relationship is strong, Japan is not a member of NATO. As the country was limited in its ability to participate in military operations, Japan wanted to be recognized as a good member and contributor to the international community. To that end, Japan assumed a big responsibility by contributing to the IMF, the World Bank, and through bilateral ODA (Nakao 2004). ${ }^{39}$

Some might ascribe this policy change to coercion. The picture of intransigence and policy movement in the face of international bullying is familiar; the Japanese word for this is gaiatsu (Schoppa 1993). However, other G-7 creditors were unlikely to punish the Japanese for failure to support debt relief. Donor agreements are not legally binding but are recommendations to sovereign governments. An IMF report on free-riding behavior found that "moral suasion" was the primary tool donors possessed or were willing to use to persuade recalcitrant creditors (Nankani and Geithner 2003). Schoppa argues that gaiatsu is more likely to be successful when "latent support for foreign demands exists outside the privileged elite" (Schoppa 1993, 385). External pressure must go through domestic actors and find bases of support. The religious appeal for debt relief did not resonate in Japan. However, the frame - where debt relief was seen as a test of Japan's international contribution - tapped into the domestic conversation about "internationalizing" Japan that had been nearly a national "obsession" in the 1980s (Ohta $1995,247)$. By the 1990s, polls consistently showed that more than $80 \%$ of the Japanese public thought that "internationalizing" Japan was either "necessary to ensure Japan's future prosperity" or appropriate because "now that Japan has become a major developed country, it has to become more internationalized" (JPOLL, Undated). Reframing debt relief as a diplomatic issue also empowered the Foreign Ministry in internal bureaucratic debates with the other main gatekeeper, the Finance Ministry.

In a broader sense, Japan's national interest could have suffered from incremental "reputational" damage as an unreliable partner (Simmons 1998). However, these concerns about national prestige and trying to be good allies and global citizens are more deeply rooted than a materialist cost-benefit calculation. As Keohane has argued, normative foundations ultimately underpin support for "diffuse reciprocity." He noted that "the actor making a short-run sacrifice does not know that future benefits will flow from comparable restraint by others, and can hardly be regarded as making precise calculations of expected utility" (Keohane 1982:342). Indeed, Japanese decisions to be reliable cooperators are based on an embedded idea of material interest that, in a sense, has become an end in itself (Legro 2005:7).

\section{Concluding Comments}

The approach of this article-taking the configuration of costs, values, and veto powers - is widely applicable to other issues politicized by transnational advocacy groups. The mapping exercise in policy space provides a first-cut approximation of the likelihood of moral action by states. While there are likely to be issue areas and situations of such high costs and risks that decision-makers do ignore ideational factors, the approach can be applied to cases as diverse as climate change, HIV/ AIDS, and the International Criminal Court. Debt relief writ large likely had a better chance of commanding broader international support than other issues like climate change because the costs of the entire initiative required less behavioral and policy change. However, Japanese and Canadian support for the Kyoto Protocol in the face of high costs provide additional support for the argument that ideational

\footnotetext{
${ }^{39}$ See also Lumsdaine on reputational concerns in Japanese foreign assistance (Lumsdaine 1993).
} 
attachments can offset purely material accounts of short-run interests. Gatekeepers analysis adds an important layer and gets at the constellation of veto players that need to be accommodated as advocates try to translate their appeals into policy. While the mechanism of strategic framing may not be dominant in every successful case of advocacy, this article establishes testable implications of its scope conditions. One central finding is that policy gatekeepers are prepared to invest significant, albeit limited, amounts of resources to support norms-based policies when advocates have tapped into values that have broader societal appeal as well as personal meaning. Subsequent studies in other issue domains and countries are required to establish the frequency of such situations.

\section{References}

Acharya, Amitav. (2004) How Ideas Spread: Whose Norms Matter? Norm Localization and Institutional Change in Asian Regionalism. International Organization 58(1):239-275.

Apocalyptic in America. (1999) The Guardian. September 20.

Armingeon, Klaus, Philipp Leimgruber, Michelle Beyeler, and Sarah Menegale. (2005) Comparative Political Data Set 1960-2003, Institute of Political Science, University of Berne. Available at http://www.ipw.unibe.ch/content/team/klaus_armingeon/comparative_political_data_sets/index_ ger.html. (Accessed August 15, 2006).

Arslanalp, Serkan, and Peter Blair Henry. (2006) Policy Watch: Debt Relief. Journal of Economic Perspectives 20(1):207-220.

Axelrod, Robert. (1984) The Evolution of Cooperation. New York: Basic Books.

Beattie, Alan. (2000) Magic bullet may be flash in the pan. Financial Times. September 22.

Betsill, Michele M. (2000) Greens in the Greenhouse: Environmental NGO's, International Norms and the Politics of Global Climate Change, Unpublished dissertation, University of Colorado, Boulder.

Birdsall, Nancy, and John Williamson. (2002) Delivering on Debt Relief. Washington, DC: Center for Global Development.

Bono, And Michka Assayas. (2005) Bono: In Conversation With Michka Assayas. New York: Riverhead Books.

Bueno de Mesquita, Bruce, Alastair Smith, Randolph M. Siverson, and James D. Morrow. (2003) The Logic of Political Survival. Cambridge, MA: MIT Press.

Callaghy, Thomas. (2001) North-South Relations: Reconfiguration of the Debt Regime. Annual Meeting of the American Political Science Association, San Francisco, California.

Callahan, Sonny. (2005) Personal communication, former member of Congress (R-Alabama). January 27.

Cardenas, Sonia. (2004) Norm Collision: Explaining the Effects of International Human Rights Pressure on State Behavior. International Studies Review 6(2):213-232.

Carpenter, R. Charli. (2005) Women, Children and Other Vulnerable Groups: Gender, Strategic Frames, and the Protection of Civilians as a Transnational Issue. International Studies Quarterly 49(2):295-394.

Castellano, Marc. (2000) G-7 Poor-Country Debt-Relief Initiative Faces Difficulties. Japan Economic Institute Report 27.

Checkel, Jeffrey T. (1997) International Norms and Domestic Politics: Bridging the RationalistConstructivist Divide. European Journal of International Relations 3(4):473-495.

Checkel, Jeffrey T. (1999) Norms, Institutions, and National Identity in Contemporary Europe. International Studies Quarterly 43(1):84-114.

Checkel, Jefreey T. (2001) Why Comply? Social Learning and European Identity Change. International Organization 55(3):553-588.

Clinton, Bill. (1999) Remarks by the President to Conference on U.S.-Africa Partnership for the 21 st Century, The White House, Office of the Press Secretary. Available at http://www.state.gov/ www/regions/africa/990316_clinton.html. (Accessed August 15, 2006).

Cortell, Andrew, and James W. Davis. (2000) Understanding the Domestic Impact of International Norms: A Research Agenda. International Studies Review 2(1):65-87.

Cortell, Andrew P., and James W. Davis. (2005) When Norms Clash: International Norms, Domestic Practices, and Japan's Internalisation of the GATT/WTO. Review of International Studies, (31): $3-25$.

Crook, Clive. (1991) Sisters in the Woods. The Economist, October 12. 
Dent, Martin, And Bill Peters. (1999) The Crisis of Poverty and Debt in the Third World. Aldershot: Ashgate Publishing Company.

Development Committee. (2005) Note on the G8 Debt Relief Proposal, World Bank/IMF. Available at http://siteresources.worldbank.org/IDA/Resources/G8DebtPaperSept05.pdf. (Accessed August 15, 2006).

Dominus, Susan. (2000) Questions for Bono; Relief Pitcher. New York Times, October 8.

Donnelly, Elizabeth A. (Undated) Proclaiming the Jubilee: The Debt and Structural Adjustment Network, UN Vision Project on Global Public Policy Network. Available at http://www.global publicpolicy.net/fileadmin/gppi/Donnelly_Jubilee.pdf. (Accessed August 15, 2006).

Drummond, Jamie. (2001) Personal Communication, formerly with the Jubilee 2000 Campaign. January.

Easterly, William. (2001) Think Again: Debt Relief. Foreign Policy 127:20-26.

Farrell, Theo. (2001) Transnational Norms and Military Development: Constructing Ireland's Professional Army. European Journal of International Relations 7(1):63-102.

Fearon, James, and Alexander Wendt. (2003) Rationalism v. Constructivism: A Skeptical View. In Handbook of International Relations, edited by W. Carlsnaes, T. Risse-Kappen, and B. A. Simmons. London: SAGE Publications.

Finnemore, Martha. (1996) National Interests in International Society. Ithaca: Cornell University Press.

Finnemore, Martha, and Kathryn Sikkink. (1999) Norm Dynamics and Political Change. In Exploration and Contestation in the Study of World Politics, edited by P. Katzenstein, R. Keohane and S. Krasner. Cambridge: MIT Press.

GAO. (2000) Debt Relief Initiative for Poor Countries Faces Challenges GAO/NSIAD-00-161. Washington, DC: Government Accounting Office. Available at http://www.gao.gov/new.items/ns00161.pdf. (Accessed August 15, 2006).

George, Alexander L., And Andrew Bennett. (2005) Case Studies and Theory Development in the Social Sciences. Cambridge, MA: MIT Press.

Goldstein, Judith, and Robert O. Keohane. (1993) Ideas and Foreign Policy: Beliefs, Institutions, and Political Change. Ithaca: Cornell University Press.

Grunwald, Michael. (1999) GOP's Bachus Makes Debt Relief His Mission. Washington Post, October 9.

HaAs, Peter M. (1992) Introduction: Epistemic Communities and International Policy Coordination. International Organization 46(1):1-35.

Hall, Peter A. (1989) The Political Power of Economic Ideas: Keynesianism Across Nations. Princeton: Princeton University Press.

Hart, Thomas M. (2001) Personal communication, January.

Hatch, ScotT. (2005) Personal communication, April 6.

Hawkins, Darren. (2004) Explaining Costly International Institutions: Persuasion and Enforceable Human Rights Norms. International Studies Quarterly 48(4):779-804.

Hertzke, Allen D. (2004) Freeing God's Children: The Unlikely Alliance for Global Human Rights. Lanham: Rowman \& Littlefield.

Hoover, Dennis. (2001) What Would Moses Do? Debt Relief in the Jubilee Year. Available at http:// www.trincoll.edu/depts/csrpl/RINVol4No1/jubilee_2000.htm. (Accessed August 15, 2006).

Huber, Evelyne, and John D. Stephens. (2001) Development and Crisis of the Welfare State: Parties and Policies in Global Markets. Chicago: The University of Chicago Press.

Ikenberry, G. John, And Charles Kupchan. (1990) Socialization and Hegemonic Power. International Organization 44(3):283-315.

IMF. (1998) The Initiative For Heavily Indebted Poor Countries Review and Outlook. Available at http://www.imf.org/external/np/hipc/review/hipcrev.pdf. (Accessed August 15, 2006).

IMF. (2005) World Economic Outlook. Available at http://www.imf.org/external/pubs/ft/weo/2005/02/data/ index.htm. (Accessed March 15, 2005).

InGLeHART, Ronald. (2005) European and World Values Surveys Integratged Data File, 1999-2002, Release I. Ann Arbor, Inter-university Consortium for Political and Social Research. Available at http://www.worldvaluessurvey.org/.

Jackson, Patrick, and Ronald Krebs. (2007) Twisting Tongues and Twisting Arms: The Power of Political Rhetoric. European Journal of International Relations 13(1):35-66.

Jacobsen, John Kurt. (1995) Much Ado about Ideas: The Cognitive Factor in Economic Policy. World Politics 47(2):283-310.

JAPANESE MOFA Official. (2004) Personal communication, former official with Ministry of Foreign Affairs, July 22.

Jenns, Nicola. (2006) Person Communication, Department for International Development, June 5 . 
Joachim, Jutтa. (2003) Framing Issues and Seizing Opportunities: The UN, NGO's and Women's Rights. International Studies Quarterly 47(2):247-274.

Jones, Bryan D. (1994) Reconceiving Decision-Making in Democratic Politics. Chicago: University of Chicago Press.

JPOLL. (Undated) The Japanese Public Opinion Database. Available at http://www.ropercenter. uconn.edu/jpoll/JPOLL.html. (Accessed August 15, 2006).

Jubilee 2000. (2000) An Emerging Scandal. Available at http://www.jubileeresearch.org/jubilee2000/ reports/scandal.html. (Accessed August 15, 2006).

JubileE 2000. (Undated-a) Milestones in the Campaign. Available at http://www.jubileeresearch.org/ jubilee2000/about.html\#milestones. (Accessed August 15, 2006).

Jubilee 2000. (Undated-b) Too little. Too late. Available at http://www.jubileeresearch.org/jubilee2000/ politic.html. (Accessed August 15, 2006).

Kahn, Joseph. (2000) Leaders in Congress Agree to Debt Relief for Poor Nations. New York Times, October 18.

Kaufmann, Chaim D., And Robert A. Pape. (1999) Explaining Costly International Moral Action: Britain's Sixty-Year Campaign Against the Atlantic Slave Trade. International Organization 53(4):631-668.

Keck, Margaret E., And Kathryn Sikkink. (1998) Activists Beyond Borders: Advocacy in International Politics. Ithaca: Cornell University Press.

Keohane, Robert O. (1982) The Demand for International Regimes. International Organization 36(2):332-355.

Kingdon, John. (1995) Agendas, Alternatives, and Public Policies. $2^{\text {nd }}$ edition. New York: Addison-Wesley Longman Publishing Company.

Kowert, Paul, and Jeffrey Legro, eds. (1996) Norms, Identity, and Their Limits: A Theoretical Reprise. The Culture of National Security. Cornell: Cornell University Press.

Krugman, Paul. (1988) Financing Versus Forgiving a Debt Overhang. Journal of Development Economics 29(3):253-268.

Lagon, Mark. (2005) Personal communication, June 15.

Legro, JefFrey W. (1997) Which Norms Matter. Revisiting the 'Failure' of Internationalism. International Organization 51(1):31-63.

Legro, Jeffrey W. (2005) Rethinking the World: Great Power Strategies and International Order. Ithaca: Cornell University Press.

Lipson, Charles. (1981) The International Organization of Third World Debt. International Organization 35(4):603-631.

Lovett, Adrian. (2003) Personal communication, formerly with the Jubilee 2000 campaign, August 15.

Lumsdaine, David Halloran. (1993) Moral Vision in International Politics: The Foreign Aid Regime, 19491989. Princeton: Princeton University Press.

Mallaby, Sebastian. (2000) Why So Stingy on Foreign Aid? Washington Post, June 27.

Mallaby, Sebastian. (2004) World's Banker: A Story of Failed States, Financial Crises, and the Wealth and Poverty of Nations. London: Penguin Books.

Mansfield, Edward D., Helen Milner, and John Pevehouse. (2005) Vetoing Cooperation: The Impact of Veto Players on International Trade Agreements. Washington, DC: American Political Science Association.

March, James G., And Johan P. Olsen. (1998) The Institutional Dynamics of International Political Orders. International Organization 52(4):943-969.

McAdam, Doug, John D. McCarthy, and Mayer Zald. (1996) Comparative Perspectives on Social Movements. Cambridge: Cambridge University Press.

McCormick, Jamie. (2005) Personal communication, February 10.

McElroy, Robert W. (1992) Morality and American Foreign Policy: The Role of Ethics in International Affairs. Princeton: Princeton University Press.

McManus, Mike. (1999) Jubilee 2000: Debt relief for the poor. Birmingham News, October 17.

Milner, Helen. (1997) Interests, Institutions, and Information: Domestic Politics and International Relations. Princeton: Princeton University Press.

Moravcsik, Andrew. (1997) Taking Preferences Seriously: A Liberal Theory of International Politics. International Organization 51(4):513-554.

Nakao, Takehiko. (2004) Personal communication, Ministry of Finance, August 22.

Nankani, Gobind, and Timothy Geithner. (2003) Enhanced HiPC Initiative-Creditor Participation Issues, IMF. Available at http://www.imf.org/external/np/hipc/2003/creditor/040803.pdf. (Accessed August 15, 2006).

Northover, Henry. (2003) Personal communication, CAFOD, August 22. 
OECD. (2006) International Development Statistics Online. Available at http://www.oecd.org/ dataoecd/50/17/5037721.htm. (Accessed August 15, 2006).

Ohta, Hiroshi. (1995) Japan's Politics and Diplomacy of Climate Change. New York: Graduate School of Arts and Sciences, Columbia University.

Olson, Mancur. (1965) The Logic of Collective Action; Public Goods and the Theory of Groups. Cambridge: Harvard University Press.

Payne, Rodger. (2001) Persuasion, Frames and Norm Construction. European Journal of International Relations 7(1):37-61.

Peterson, Jonathan. (2001) The Rock Star, the Pope, and the World's Poor. Los Angeles Times, January 7.

Price, Richard. (2003) Transnational Civil Society and Advocacy in World Politics. World Politics 55:579-606.

Putnam, Robert. (1988) Diplomacy and Domestic Politics: The Logic of Two-Level Games. International Organization 42(3):427-460.

Riker, William H. (1986) The Art of Political Manipulation. New Haven: Yale University Press.

Risse, Thomas. (2000) Let's Argue: Communicative Action in World Politics. International Organization 54(1): 1-39.

Risse-Kappen, Thomas. (1991) Public Opinion, Domestic Structure and Foreign Policy in Liberal Democracies. World Politics 43(4):479-512.

Risse-Kappen, Thomas. (1995) Ideas Do not Float Freely. In International Relations Theory and the End of the Cold War, edited by R. N. Lebow and T. Risse-Kappen. New York: Columbia University Press.

Ruggie, John Gerard. (1999) What Makes the World Hang Together? Neo-Utilitarianism and the Social Constructivist Challenge. In Exploration and Contestation in the Study of World Politics, edited by P. Katzenstein, R. Keohane and S. Krasner. Cambridge: MIT Press.

Schimmelfennig, Frank. (2001) The Community Trap: Liberal Norms, Rhetorical Action, and the Eastern Enlargement of the European Union. International Organization 51(1):47-80.

Schoppa, LeOnard J. (1993) Two-Level Games and Bargaining Outcomes: Why Gaiatsu Succeeds in Japan in Some Cases but not Others. International Organization 47(3):353-386.

Schuerch, William E. (1999) House International Relations Committee, Subcommittee on Africa Testimony by Treasury Deputy Assistant Secretary for International Development, Debt and Environmental Policy. Available at http://www.treas.gov/press/releases/rr3079.htm. (Accessed August 15, 2006).

Sell, Susan K., and Aseem Prakash. (2004) Using Ideas Strategically: The Contest Between Business and NGO Networks in Intellectual Property Rights. International Studies Quarterly 48(1): 1430175 .

Serieux, John, and Yiagadeesen Samy, eds. (2003) Debt Relief for the Poorest Countries. New Brunswick: Transaction Publishers.

Simmons, Beth A. (1998) Compliance with International Agreements. Annual Review of Political Science $1(1): 75-93$.

Snow, David A., and Robert D. Benford. (1988) Ideology, Frame Resonance, and Participant Mobilization. In From Structure to Action: Comparing Social Movement Research Across Cultures, edited by B. Klandermans, H. Kriesi, and S. G. Tarrow. Greenwich: JAI Press.

Summers, Lawrence H. (2000) Moving Forward with Millennial Debt Relief, Reception to Celebrate HIPC House Banking Committee Room, U.S. Congress, Washington, DC. Available at http:// www.treas.gov/press/releases/ls363.htm. (Accessed August 15, 2006).

Summers, Larry. (2004) Personal communication, December 9.

Sundstrom, Lisa McIntosh. (2005) Foreign Assistance, International Norms, and NGO Development: Lessons from the Russian Campaign. International Organization 59:419-449.

Tsebelis, George. (2002) Veto Players: How Political Institutions Work. New York: Russell Sage Foundation.

Vreeland, James. (2004) Institutional Determinants of IMF Agreements, Yale University, Unpublished Manuscript. Available at http://pantheon.yale.edu/ jrv9/Veto.pdf. (Accessed August 15, 2006).

WAGner, John. (2000) In Helms, Bono Finds the Ally He's Looking For. Raleigh News and Observer, September, 21.

World BANK. (1999a) HIPC Debt Tables. Available at http://web.archive.org/web/20001004200454/ www.worldbank.org/hipc/about/debt-table/iil.pdf. (Accessed August 15, 2006).

World BANK. (1999b) Outcome of the 1999 Review. Available at http://siteresources.worldbank.org/ INTDEBTDEPT/PolicyPapers/20252909/1999-Outcome-Review-1.pdf. (Accessed August 15, 2006). 
World BANK. (2001) The HIPC Initiative: Background and Progress Through December 2001. Available at http://web.archive.org/web/20020606135441/http:www.worldbank.org/hipc/progress-todate/May99v3/may99v3.htm. (Accessed August 15, 2006).

World BANK. (2006) HIPC Initiative-Status of Implementation. Available at http://siteresources. worldbank.org/INTDEBTDEPT/ProgressReports/20894658/032106.pdf. (Accessed August 15, 2006).

World BAnk. (Undated-a) Debt Issues. Available at www.worldbank.org/debt. (Accessed August 15, 2006).

WORLD BANK. (Undated-b) HIPC map. Available at http://web.archive.org/web/20030217010431/ http:www.worldbank.org/hipc/about/map/map.html. (Accessed August 15, 2006).

Yasutomo, Dennis T. (1995) The New Multilateralism in Japan's Foreign Policy. New York: St. Martin's Press.

Zald, Mayer. (1996) Culture, Ideology and Strategic Framing. In Comparative Perspectives on Social Movements, edited by D. McAdam, J. D. McCarthy, and M. Zald. Cambridge: Cambridge University Press. 
